\title{
PREDICTING THE PHYSICAL PROPERTIES OF DRAWN NYLON-6 FIBERS USING AN ARTIFICIAL-NEURAL-NETWORK MODEL
}

\author{
NAPOVEDOVANJE FIZIKALNIH LASTNOSTI VLEČENIH \\ VLAKEN IZ NAJLONA 6 Z UPORABO MODELA UMETNE \\ NEVRONSKE MREŽE
}

\author{
Ruhollah Semnani Rahbar', Morteza Vadood ${ }^{2}$ \\ ${ }^{1}$ Department of Textile and Leather, Faculty of Chemistry and Petrochemical Engineering, Standard Research Institute (SRI), Karaj, \\ P. O. Box 31745-139, Iran \\ ${ }^{2}$ Department of Textile Engineering, Amirkabir University of Technology, Tehran, Iran \\ semnani@standard.ac.ir
}

Prejem rokopisa - received: 2013-08-13; sprejem za objavo - accepted for publication: 2014-07-11

doi: $10.17222 /$ mit. 2013.128

\begin{abstract}
Low-oriented nylon-6 fibers were drawn in a multistage drawing process, during which the number of drawing steps and the temperature of each step were changed. The physical properties of these fibers were measured and compared with the values predicted by a multiple-linear-regression model. Moreover, six input variables and four output variables were used in an artificial neural network (ANN) to establish the logical relationships between the inputs and outputs. Attempts were also made to determine the effective parameters for each physical property and explain the observed trends. The results showed that the models based on the ANN performed well and provided stable responses in predicting combined interactions between
\end{abstract} independent variables.

Keywords: drawing process, artificial neural network, modeling, physical properties

\begin{abstract}
Malo orientirana vlakna najlon 6 so bila vlečena z večstopenjskim postopkom, pri čemer se je pri vsakem vleku spreminjala stopnja vlečenja in temperatura. Izmerjene vrednosti teh vlaken so bile primerjane z vrednostmi, napovedanimi z modelom multivariantne linearne regresije. Poleg tega je bilo v umetni nevronski mreži (ANN) uporabljenih šest vhodnih spremenljivk in štiri izhodne, da bi ugotovili logične odvisnosti med vhodnimi in izhodnimi spremenljivkami. Poskušalo se je ugotoviti učinkovite parametere za vsako fizikalno lastnost in razložiti opažene tendence. Rezultati so pokazali, da so modeli na osnovi ANN dobri in ponujajo stabilne odgovore pri predvidevanju kombiniranih interakcij neodvisnih spremenljivk.

Ključne besede: postopek vlečenja, umetna nevronska mreža, modeliranje, fizikalne lastnosti
\end{abstract}

\section{INTRODUCTION}

Synthetic-fiber drawing is a critical process to obtain fibers with desired properties for final applications. There are various parameters in this process that should be controlled to yield a fiber with acceptable technical specifications. These variables include the draw ratio, the drawing temperature, the number of drawing steps, the drawing speed and the distribution of draw ratio in the multistage drawing ${ }^{1}$. Because of the complex relationships between the fiber properties and the drawing-process variables, there is a need for a sound experimental design and a careful analysis of the experimental results. In this way, the relationships between a measured characteristic of a drawn fiber and the influencing factors can be identified and optimized. The understanding of these relationships reduces the processing cost and provides for reproducibility in a day-to-day production. Moreover, the risk of excessive downtime for trials is reduced $^{2-5}$.

Due to their simplicity, regression-based models and statistical analyses were extensively used to solve textile technological problems ${ }^{2-4,6-9}$. However, they have certain limitations as they require a specialized knowledge of both the statistical methods and techniques of experimental design. Moreover, the prediction ability of the regression analysis may be limited in the case of an analysis of multidimensional technical problems ${ }^{10,11}$.

In recent years, artificial neural network (ANN) has been used as an alternative modeling method in many different engineering fields to predict the properties of materials. ANN can be considered as a black box consisting of a series of complex equations for estimating the outputs on the basis of a given series of input values. The advantage of ANNs is the ability of representing complex relationships directly from the data being modeled, while their representation (modeling) is always nonlinear ${ }^{12-14}$.

Many researches were done in the textile industry to predict the properties of yarns, woven and nonwoven fabrics and many other characteristics of textile materials $^{10,13-25}$. Among these, just few studies are devoted to melt spinning and drawing of synthetic fibers. It seems that there is a lack of information concerning the appli- 
cation of ANN for predicting fiber properties during multistage drawing. Therefore, in this paper, an ANN model was used to predict some physical properties of drawn nylon-6 fibers upon multistage drawing.

\section{EXPERIMENTAL WORK}

\subsection{Materials and methods}

A low-oriented nylon-6 multifilament yarn, 340 dtex, 24 filaments, was kindly supplied by Alyaf Co. (Iran). Nylon 6 (polyamide 6) is made up of linear macromolecules whose structural units are linked with an amide linkage (-NH-CO-group). This synthetic fiber is used for a variety of different applications ranging from garments to industrial usages.

Fiber samples were prepared by melt spinning and the take-up speed of $800 \mathrm{~m} / \mathrm{min}$. The undrawn multifilament yarn had a polymerization degree of 148 . The drawing process was performed on an industrial Zinser draw-twisting machine (Germany), type 520-2. The details of the drawing process were explained in the previous work ${ }^{26}$. The fixed drawing conditions are listed in Table 1.

Table 1: Fixed operating conditions of the drawing experiments Tabela 1: Pogoji obratovanja pri preizkusih vlečenja

\begin{tabular}{|c|c|c|c|c|}
\hline $\begin{array}{c}\text { Temperature } \\
\text { of the feeding } \\
\text { roller }\left({ }^{\circ} \mathrm{C}\right)\end{array}$ & $\begin{array}{c}\text { Temperature } \\
\text { of the third } \\
\text { godet roller } \\
\left({ }^{\circ} \mathrm{C}\right)\end{array}$ & $\begin{array}{c}\text { Drawing } \\
\text { speed } \\
(\mathrm{m} / \mathrm{min})\end{array}$ & $\begin{array}{c}\text { Intermingling } \\
\text { jet pressure } \\
(\mathrm{bar})\end{array}$ & $\begin{array}{c}\text { Spindle } \\
\text { speed } \\
(\mathrm{r} / \mathrm{min})\end{array}$ \\
\hline $\begin{array}{c}\text { Room } \\
\text { temperature }\end{array}$ & $\begin{array}{c}\text { Room } \\
\text { temperature }\end{array}$ & 400 & 2 & 4000 \\
\hline
\end{tabular}

Six process parameters of drawing trials included the first-stage draw ratio $(F S D R)$, the second-stage draw ratio $(S S D R)$, the third-stage draw ratio $(T S D R)$, the firstgodet temperature $(F G T)$, the block-heater temperature $(B H T)$, and the second-godet temperature $(S G T)$. In the trials, one-, two- and three-stage drawn fibers and also the fiber heat-treated without drawing were produced to have a broad range of fibers with different structures. A total of 61 different fibers were prepared and the drawing trials are reported in Table 2.

Table 2: Experimental array for the drawing process Tabela 2: Pogoji eksperimenta pri postopku vlečenja

\begin{tabular}{|c|c|c|c|c|c|c|}
\hline Run & 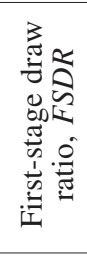 & 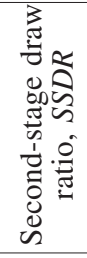 & 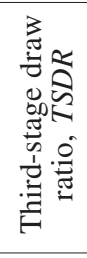 & 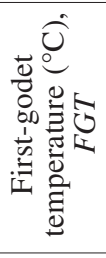 & 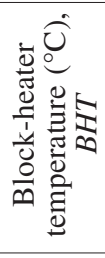 & 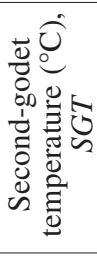 \\
\hline 1 & 1.1 & 4.126 & 1.3 & 100 & 170 & 170 \\
\hline 2 & 2.098 & 1.611 & 1.626 & 100 & 170 & 170 \\
\hline 3 & 2.8 & 1.621 & 1.3 & 100 & 170 & 170 \\
\hline 4 & 1.755 & 1.5 & 1.3 & 100 & 170 & 170 \\
\hline 5 & 1.755 & 2.586 & 1.3 & 100 & 170 & 170 \\
\hline
\end{tabular}

\begin{tabular}{|c|c|c|c|c|c|c|}
\hline 6 & 1.615 & 1.884 & 1.939 & 100 & 170 & 170 \\
\hline 7 & 1.1 & 2.488 & 1.3 & 100 & 170 & 170 \\
\hline 8 & 1.1 & 2.551 & 2.102 & 100 & 170 & 170 \\
\hline 9 & 1.1 & 1.5 & 1.3 & 100 & 170 & 170 \\
\hline 10 & 1.315 & 2.074 & 1.564 & 100 & 170 & 170 \\
\hline 11 & 1.755 & 1.97 & 1.3 & 100 & 170 & 170 \\
\hline 12 & 1.348 & 1.611 & 2.53 & 100 & 170 & 170 \\
\hline 13 & 1.8 & 1.5 & 2.185 & 100 & 170 & 170 \\
\hline 14 & 1.1 & 1.5 & 2.102 & 100 & 170 & 170 \\
\hline 15 & 1.1 & 1.5 & 3.4 & 100 & 170 & 170 \\
\hline 16 & 1.637 & 1.5 & 1.792 & 150 & 170 & 170 \\
\hline 17 & 1.1 & 1.739 & 2.3 & 150 & 170 & 170 \\
\hline 18 & 1.1 & 1.5 & 1.729 & 150 & 150 & 150 \\
\hline 19 & 1.1 & 1.615 & 2.3 & 30 & 30 & 30 \\
\hline 20 & 1.1 & 3.077 & 1.3 & 150 & 150 & 150 \\
\hline 21 & 1.1 & 2.313 & 1.729 & 30 & 170 & 170 \\
\hline 22 & 1.253 & 1.975 & 1.676 & 60 & 80 & 80 \\
\hline 23 & 1.1 & 3.077 & 1.3 & 90 & 170 & 170 \\
\hline 24 & 2.1 & 1.612 & 1.3 & 150 & 170 & 170 \\
\hline 25 & 1.1 & 1.5 & 1.3 & 30 & 30 & 30 \\
\hline 26 & 1.1 & 1.5 & 1.3 & 30 & 170 & 170 \\
\hline 27 & 1.1 & 2.148 & 1.3 & 150 & 150 & 150 \\
\hline 28 & 1.1 & 1.5 & 1.3 & 90 & 90 & 90 \\
\hline 29 & 2.1 & 1.5 & 1.397 & 30 & 30 & 30 \\
\hline 30 & 1.1 & 3.077 & 1.3 & 30 & 170 & 170 \\
\hline 31 & 1.637 & 1.5 & 1.792 & 30 & 170 & 170 \\
\hline 32 & 1.275 & 1.5 & 2.3 & 30 & 100 & 100 \\
\hline 33 & 1.52 & 1.5 & 1.3 & 30 & 170 & 170 \\
\hline 34 & 1.732 & 1.591 & 1.506 & 90 & 110 & 110 \\
\hline 35 & 1.52 & 2.227 & 1.3 & 30 & 30 & 30 \\
\hline 36 & 1.1 & 1.5 & 1.3 & 150 & 170 & 170 \\
\hline 37 & 2.1 & 1.612 & 1.3 & 30 & 170 & 170 \\
\hline 38 & 1.1 & 1.5 & 2.3 & 30 & 170 & 170 \\
\hline 39 & 1.1 & 3.077 & 1.3 & 30 & 30 & 30 \\
\hline 40 & 1.637 & 1.5 & 1.792 & 30 & 30 & 30 \\
\hline 41 & 1.275 & 1.5 & 2.3 & 90 & 90 & 90 \\
\hline 42 & 1.1 & 1.5 & 1 & 100 & 170 & 170 \\
\hline 43 & 1.1 & 4.2 & 1 & 100 & 170 & 170 \\
\hline 44 & 1.1 & 4.2 & 1.3 & 100 & 170 & 170 \\
\hline 45 & 2.8 & 1 & 1 & 30 & 30 & 30 \\
\hline 46 & 2.8 & 1 & 1 & 100 & 30 & 30 \\
\hline 47 & 1.1 & 4.126 & 1.3 & 100 & 30 & 170 \\
\hline 48 & 1.1 & 4.126 & 1.3 & 100 & 60 & 170 \\
\hline 49 & 1.1 & 4.126 & 1.3 & 100 & 100 & 170 \\
\hline 50 & 1.1 & 4.126 & 1.3 & 100 & 150 & 170 \\
\hline 51 & 1.008 & 4.6 & 1 & 100 & 170 & 170 \\
\hline 52 & 1.1 & 4.215 & 1 & 100 & 170 & 170 \\
\hline 53 & 1.1 & 3.242 & 1.3 & 100 & 170 & 170 \\
\hline 54 & 2.8 & 1.648 & 1.3 & 100 & 170 & 170 \\
\hline 55 & 2.8 & 1.506 & 1.3 & 100 & 170 & 170 \\
\hline 56 & 1.187 & 1.5 & 2.5 & 30 & 30 & 30 \\
\hline 57 & 2.1 & 1.564 & 1.3 & 30 & 30 & 30 \\
\hline 58 & 1.579 & 1.5 & 1.879 & 30 & 30 & 30 \\
\hline 59 & 1.1 & 1 & 1 & 30 & 30 & 30 \\
\hline 60 & 1.1 & 1 & 1 & 100 & 30 & 30 \\
\hline 61 & 1 & 1 & 1 & 100 & 30 & 30 \\
\hline
\end{tabular}

The yarn linear density (expressed in dtex) was determined in accordance with ASTM D 1577-96. The mean value is the average of five measurements. 
Stress-strain curves were obtained with an EMT-3050 tensile testing machine (Elima Co., Iran). The initial lengths of the fibers and cross-head speeds were $300 \mathrm{~mm}$ and $500 \mathrm{~mm} / \mathrm{min}$, respectively. From the stress-strain plots, the initial modulus, the tenacity and the specific work of rupture were evaluated. The reported values for all the mechanical properties were averaged over at least ten independent measurements.

Yarn-shrinkage measurements were made according to DIN 53840 at $130{ }^{\circ} \mathrm{C}$ for $10 \mathrm{~min}$. The initial and final lengths were measured at room temperature and the total shrinkage was defined as the fraction of the initial sample length remaining after the exposure to the elevated temperature. The reported values are the average of eight tests.

\subsection{Artificial neural network}

Neural networks are mainly composed of the processing elements called neurons with interconnections. The exclusive structure of an ANN makes it very appropriate for modeling a complex system with nonlinear relations between the parameters. Generally, an ANN can be made of many layers, namely the input, output and several hidden layers. The neurons in each layer are connected with the associated weights to the other neurons in the next layer. The input layer receives the input parameters and, through the hidden layers based on Equation (1), the output can be calculated in the output layer ${ }^{19}$. Figure 1 indicates the topology of an ANN with one hidden layer:

$$
y_{k}=f\left(\sum_{j=1}^{m} w_{j k} f\left(\sum_{i=1}^{n} w_{i j} x_{i}+b_{1 j}\right)+b_{2 k}\right)
$$

Here $w_{i j}, w_{j k}, b_{1 j}$ and $b_{2 k}$ are the weight between the $i^{\text {th }}$ input neuron and the $j^{\text {th }}$ hidden neuron, the weight bet-

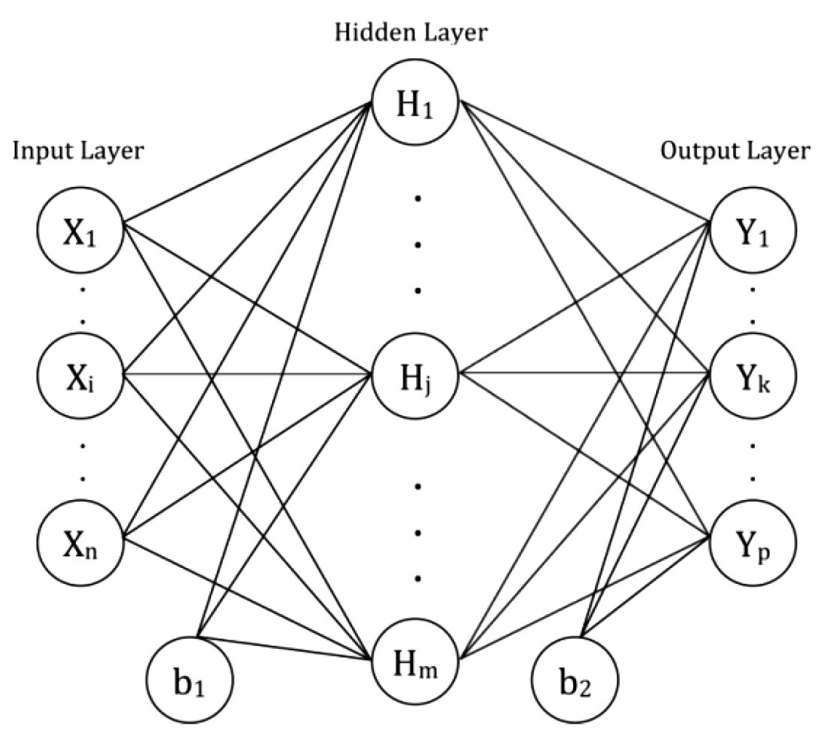

Figure 1: ANN with one hidden layer Slika 1: ANN z eno skrito plastjo ween the $j^{\text {th }}$ hidden neuron and the $k^{\text {th }}$ output neuron, the bias for the $j^{\text {th }}$ hidden neuron and the bias for the $k^{\text {th }}$ output neuron, respectively. The $f(x)$ is the activation function $^{27,28}$. All the data is divided into three groups known as the training, validation and testing sets. The first group is used to train the ANN. When the network begins to overfit the data, the training is stopped for a specified number of iterations (maximum number of fails) and the weights and biases are returned with the minimum error on the validation set. The testing group is used to control the error after the training process ${ }^{21}$. In this study, to apply ANNs, the Matlab R2008 software was used. The ANNs were trained on the basis of the error back-propagation algorithm using the "Trainlm" function to avoid an over-fitting error. The activation functions for all the hidden and output layers were considered as the hyperbolic tangent and linear function, respectively (this type of ANN is called the perceptron).

\section{RESULTS AND DISCUSSION}

\subsection{Linear regression model}

In this research, multiple linear regression (MLR) was employed to evaluate the performance of different models. In order to determine the variables that can directly affect the physical properties, as well as decreasing the number of variables, a traditional linearregression model at the $90 \%$ confidence level was accomplished. This procedure was only used for three variables including the FSDR, SSDR and TSDR because they were varied at multiple levels. The FSDR, SSDR and TSDR were changed at the $18^{\text {th }}, 21^{\text {st }}$ and $17^{\text {th }}$ levels, respectively. Moreover, theses parameters were individually considered with respect to the responses of the linear-regression model. Table 3 shows the Pearson correlation coefficient $(P C C)$ and the corresponding $P$-value between the measured parameters (FSDR, SSDR and $T S D R$ ) and the physical properties.

Table 3: $P C C$ and $P$-value between the measured parameters and physical properties

Tabela 3: $P C C$ in $P$-vrednost med izmerjenimi parametri in fizikalnimi lastnostmi

\begin{tabular}{|l|c|c|c|c|c|c|c|c|}
\hline & \multicolumn{2}{|c|}{ Shrinkage } & \multicolumn{2}{c|}{$\begin{array}{c}\text { Specific work } \\
\text { of rupture }\end{array}$} & \multicolumn{2}{c|}{ Tenacity } & \multicolumn{2}{c|}{$\begin{array}{c}\text { Initial } \\
\text { modulus }\end{array}$} \\
\hline & $P C C$ & $\begin{array}{c}P- \\
\text { value }\end{array}$ & $P C C$ & $\begin{array}{c}P- \\
\text { value }\end{array}$ & $P C C$ & $\begin{array}{c}P- \\
\text { value }\end{array}$ & $P C C$ & $\begin{array}{c}P- \\
\text { value }\end{array}$ \\
\hline FSDR & 0.23 & 0.08 & -0.25 & 0.05 & 0.23 & 0.08 & 0.25 & 0.06 \\
\hline SSDR & -0.19 & 0.14 & -0.49 & 0.00 & 0.59 & 0.00 & 0.31 & 0.01 \\
\hline TSDR & 0.38 & 0.00 & -0.32 & 0.01 & 0.14 & 0.29 & 0.36 & 0.00 \\
\hline
\end{tabular}

The $P C C$ varies between -1 and 1 ; the more absolute value of the $P C C$ indicates the existence of a strong relation between two parameters. $P$-values are used for testing the hypothesis of no correlation. Each $P$-value is the probability of getting a correlation as large as the observed value by random chance when the true correlation is zero. If a $P$-value is less than 0.1 , the corresponding 
correlation is significant. But the data for the $F G T, B H T$ and $S G T$ were different and they were varied only at the $5^{\text {th }}, 9^{\text {th }}$ and $7^{\text {th }}$ levels, respectively. Hence, a one-way ANOVA was used to evaluate their effects on the physical properties and the results are listed in Table 4 . The confidence level was $90 \%$. As mentioned before, the parameters with the $P$-value below 0.1 have a significant effect on the physical parameters. The greater the $F$-value, the greater are the influence and the relevance of the source factor.

Table 4: ANOVA results identifying the statistical significance of $F G T, B H T$, and $S G T$ for the physical properties

Tabela 4: Rezultati ANOVA prikazujejo statistično pomembnost $F G T$, $B H T$ in $S G T$ na fizikalne lastnosti

\begin{tabular}{|c|c|c|c|c|c|}
\hline & Shrinkage & $\begin{array}{l}\text { Specific } \\
\text { work of } \\
\text { rupture }\end{array}$ & Tenacity & $\begin{array}{l}\text { Initial } \\
\text { modulus }\end{array}$ \\
\hline \multirow{5}{*}{2} & $S S E$ & 103.202 & 62.662 & 4003.172 & 386497.497 \\
\hline & $D F$ & 4.000 & 4.000 & 4.000 & 4.000 \\
\hline & $M S E$ & 25.801 & 15.665 & 1000.793 & 96624.374 \\
\hline & $F$ & 3.480 & 0.703 & 5.435 & 2.339 \\
\hline & $P$ & 0.013 & 0.593 & 0.001 & 0.066 \\
\hline \multirow{5}{*}{$\underset{\infty}{Ð}$} & $S S E$ & 185.671 & 240.453 & 3159.013 & 710707.421 \\
\hline & $D F$ & 8.000 & 8.000 & 8.000 & \begin{tabular}{|l|}
8.000 \\
\end{tabular} \\
\hline & $M S E$ & 23.209 & 30.057 & 394.877 & 88838.428 \\
\hline & $F$ & 3.627 & 1.461 & 1.841 & 2.323 \\
\hline & $P$ & 0.002 & 0.194 & 0.090 & 0.033 \\
\hline \multirow{5}{*}{ ర్ } & $S S E$ & 176.808 & 235.435 & 3412.317 & 694829.932 \\
\hline & $D F$ & 6.000 & 6.000 & 6.000 & 6.000 \\
\hline & $M S E$ & 29.468 & 39.239 & 568.720 & 115804.989 \\
\hline & $F$ & 4.659 & 1.971 & 2.817 & 3.119 \\
\hline & $P$ & 0.001 & 0.086 & 0.019 & 0.011 \\
\hline
\end{tabular}

$S S E$ : sum of squares, DF: degree of freedom, MSE: mean squared error, $F: F$-statistic (the ratio of the mean squares), $P: P$-value

According to Tables 3 and $\mathbf{4}$, the effective factors for each physical property were determined and shown in Table 5.

Table 5: Parameters affecting the physical properties

Tabela 5: Parametri, ki učinkujejo na fizikalne lastnosti

\begin{tabular}{|c|c|c|c|c|}
\hline & Shrinkage & $\begin{array}{c}\text { Specific work } \\
\text { of rupture }\end{array}$ & Tenacity & $\begin{array}{c}\text { Initial } \\
\text { modulus }\end{array}$ \\
\hline FSDR & + & + & + & + \\
\hline SSDR & - & + & + & + \\
\hline TSDR & + & + & - & + \\
\hline$F G T$ & + & - & + & + \\
\hline BHT & + & - & + & + \\
\hline$S G T$ & + & + & + & + \\
\hline
\end{tabular}

$+:$ effective, $-:$ non-effective

After determining the effective parameters, multiplelinear-regression (MLR) analyses based on Table 5 were performed. The results (Figure 2) indicated that the developed MLR models provided different predictions for the physical properties.

According to Figure 2, MLR can predict the specific work of rupture and the shrinkage with the highest and
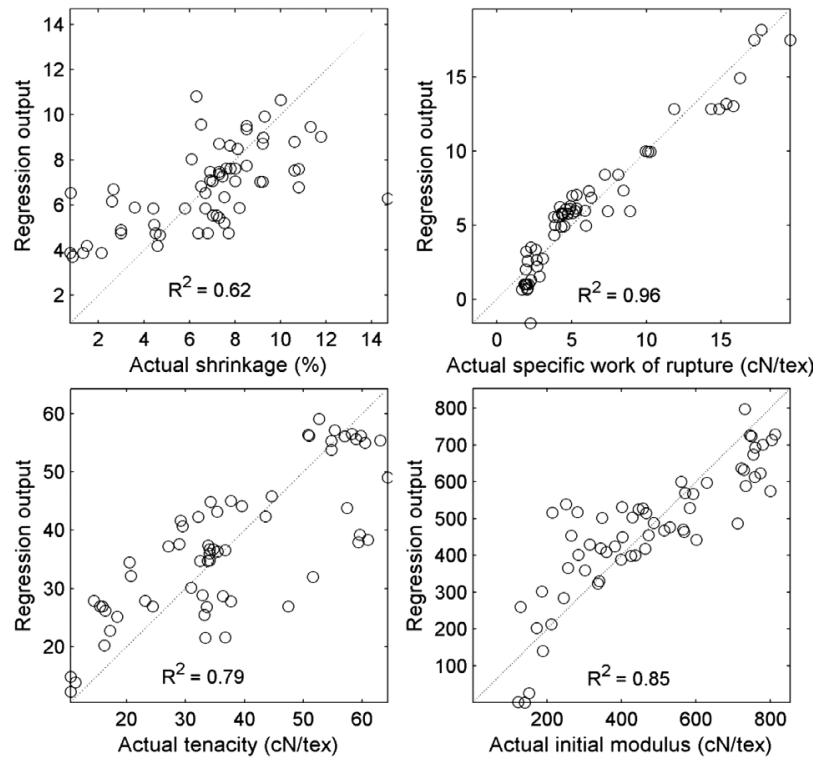

Figure 2: Results of the MLR prediction for various physical properties $\left(R^{2}=P C C\right)$

Slika 2: Rezultati MLR-napovedovanja različnih fizikalnih lastnosti $\left(R^{2}=P C C\right)$

the lowest accuracies, respectively. Table 6 shows the coefficients of MLR for predicting physical properties. Actually, each coefficient in MLR is a partial derivative of the model response with respect to the variable of that coefficient. So, the contribution of each variable in predicting the model response can be assessed by checking the coefficient values.

Referring to Table 6, the TSDR and the SGT have the highest and the lowest effects on the shrinkage, respectively. A similar trend was observed for the specific work of rupture. Moreover, for the tenacity and the initial modulus, the FSDR and the TSDR play the main roles, respectively. Also, the $B H T$ and the $F G T$ have the lowest effects on the tenacity and the initial modulus, respectively. Although increasing the order of the regression equation gives better results, it makes the regression equation more complicated. For example, using a quadratic regression including linear, interaction and square terms to predict the initial modulus increases the number of coefficients up to 28. Therefore, using an ANN model in this situation can be very beneficial. The ANN contains various parameters such as the number of hidden layers and the number of neurons in each hidden layer that directly affect the output of the ANN. Hence, to determine the best set of the ANN parameters, the trialand-error method was applied. The numbers of hidden layers and neurons in each hidden layer were considered to be between 1 to 5 and 1 to 6 , respectively. In this study the stopping criteria for the ANN training were the following three options: the training tolerance level (0), the maximum number of fails (6 iterations) or the total number of iterations for training (1000 iterations). The experimental data were used to train the network; 37, 12 and 12 data sets were randomly chosen for the training, 
validation and testing groups, respectively. To evaluate the accuracy of the developed ANN, the absolute value of the $P C C$ between the ANN outputs and the actual values for the testing set was calculated. A higher $P C C$ indicates a higher accuracy of the ANN. To remove the effects of the initial weights and biases on the ANN output, each ANN structure was created five times with the weights and biases chosen randomly and the ANN with the highest absolute value of the $P C C$ was considered for that structure.

Table 6: Coefficients of MLR models for predicting the physical properties

Tabela 6: Koeficienti MLR-modela za napovedovanje fizikalnih lastnosti

\begin{tabular}{|c|c|c|c|c|}
\hline & Shrinkage & $\begin{array}{c}\text { Specific } \\
\text { work of } \\
\text { rupture }\end{array}$ & Tenacity & $\begin{array}{c}\text { Initial } \\
\text { modulus }\end{array}$ \\
\hline Constant & 1.777 & 36.461 & -14.612 & -697.759 \\
\hline$F S D R$ & 1.688 & -6.795 & 15.768 & 251.684 \\
\hline$S S D R$ & - & -4.518 & 10.865 & 115.788 \\
\hline$T S D R$ & 2.899 & -6.892 & - & 270.758 \\
\hline$F G T$ & 0.008 & - & -0.014 & 0.347 \\
\hline$B H T$ & -0.023 & - & -0.010 & -1.231 \\
\hline$S G T$ & 0.003 & -0.002 & 0.065 & 2.084 \\
\hline
\end{tabular}

Unlike the regression method, an ANN can predict physical properties simultaneously with four neurons in the output layer, but such results showed an insufficient accuracy. In this way the prediction ability of an ANN for each output neuron only involves the weights between the last hidden layer and the output layer; so, considering separate ANNs for each physical property (one neuron in the output layer) would give a higher accuracy in the prediction. As the ANN calculations using computers can be performed quickly, to consider all the terms of the effects, such as linear terms or interactions, all the input parameters were considered for the ANN models. As expected, it was found that the structure of the neural network for each physical property was different and exhibited a high prediction performance of the
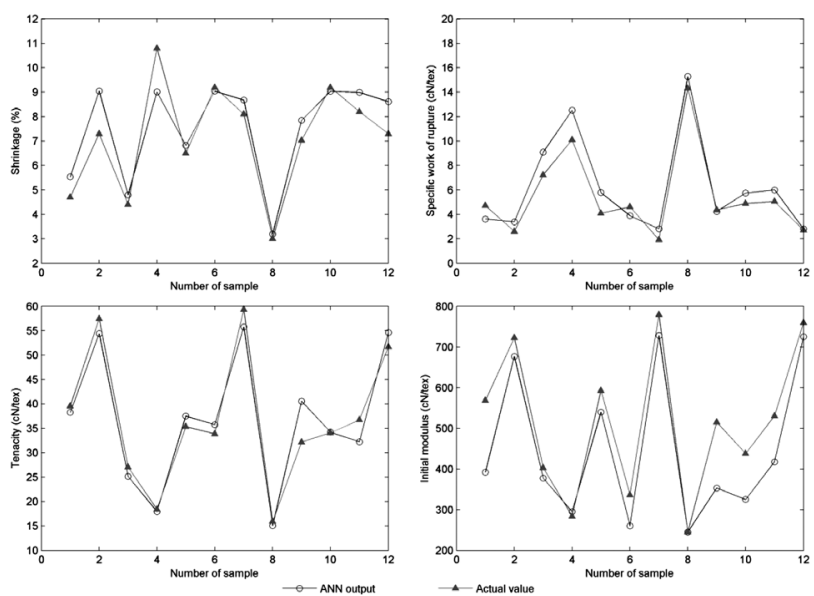

Figure 3: Predictions of ANN models for the testing group Slika 3: Napovedi ANN-modelov za preizkušeno skupino models in terms of the $P C C$, as given in Table 7. The individual values of the predictions of the models, along with the experimental values, are shown in Figure 3. By comparing Table 7 and Figure 2, it can be found that the prediction potential of the ANN models is superior to that of the MLR. This means that removing some input variables could not enhance the quality of the MLR predictions as compared to the ANN models.

Table 7: Best ANN structure for predicting various mechanical properties

Tabela 7: Najboljša struktura ANN za napovedovanje različnih mehanskih lastnosti

\begin{tabular}{|c|c|c|}
\hline Physical property & Maximum $P C C$ & Hidden layer \\
\hline Shrinkage & 0.9182 & {$[1-1-2]$} \\
\hline Specific work of rupture & 0.9907 & {$[3]$} \\
\hline Tenacity & 0.981 & {$[3-4-2]$} \\
\hline Initial modulus & 0.9917 & {$[2-1-3]$} \\
\hline
\end{tabular}

In Table 7, [1-1-2] in the hidden-layer column means that the ANN contains three hidden layers with 1, 1 and 2 neurons in the first, second and third hidden layers, respectively. As can be seen in Figure 2, the $P C C$ value for the specific work of rupture modeled with MLR is 0.96 , indicating that the relation between this parameter and its effective variables is not complicated. Also, according to Table 7, a simple ANN can model the specific work of rupture with the $P C C$ value of almost 1 which indicates a perfect prediction. As observed from Table 7, there is an increase in the $P C C$ values for the shrinkage, tenacity and initial modulus compared to the values of the MLR predictions as shown in Figure 2. This means that the relations between the parameters are no longer linear and the MLR prediction is not reliable any more, whereas the ANN using multilayers could predict these responses very well.

\subsection{Sensitivity analysis of the ANN model}

Because of the complex and nonlinear form of the ANN analysis, a sensitivity analysis was conducted to study the influence of the input variables on the output. As a matter of fact, the aim of this analysis was to evaluate the effects of the changes in each input on the ANN output. In this process, the value of one input variable from the initial condition is slightly changed $(10-50 \%)$ and then the output value is predicted, while all the other variables are set to the selected constant values. This process is repeated for all the input variables. The robustness of the model is determined by examining how well the predictions compare with the available structural knowledge. Figure 4 shows the effects of the changes in the input variables from $-50 \%$ to $+50 \%$ in the scale of 0.1 for the physical properties. It is evident from Figure 4a that the shrinkage initially increases with the TSDR and then reaches a constant value as the TSDR moves toward higher values. The changes in the other input variables have no significant 

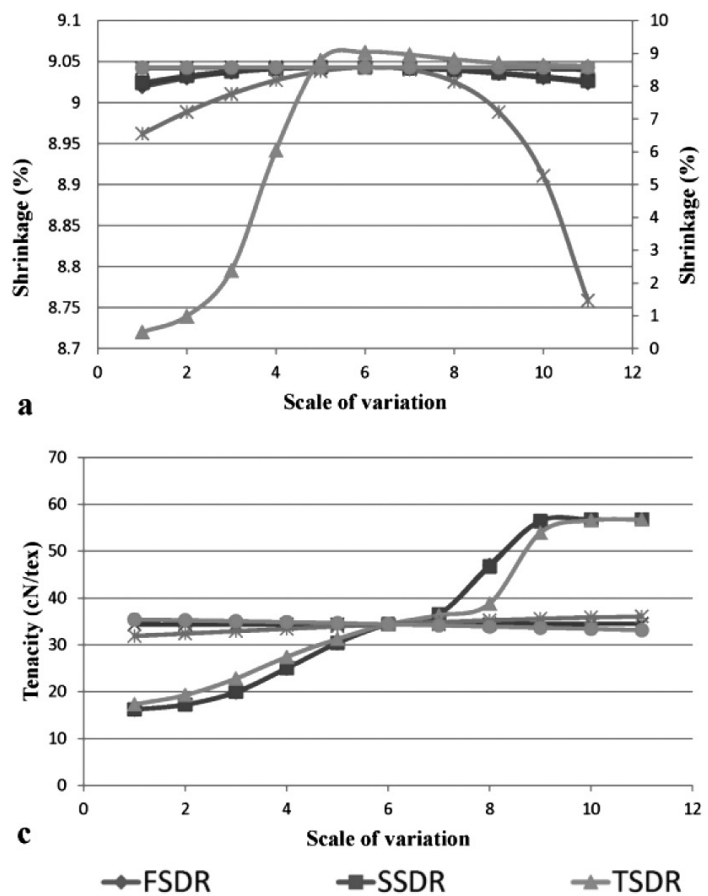
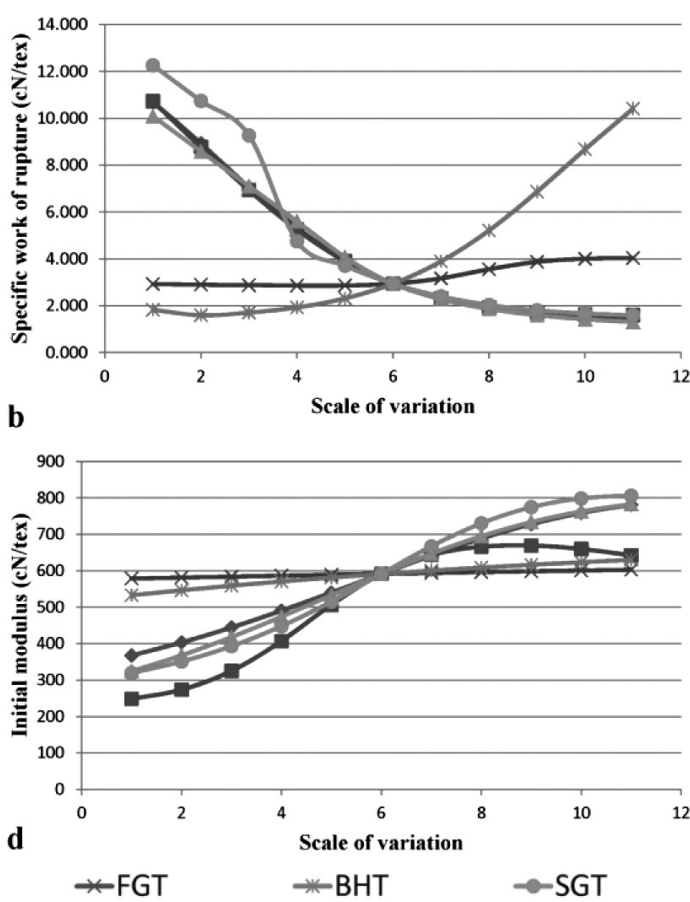

Figure 4: Effects of the changing input variables on the mechanical properties: a) shrinkage, b) specific work of rupture, c) tenacity, d) initial modulus. Since the variation of TSDR is higher than the ones of the other parameters, it is shown on the right vertical axis in Figure 4a.

Slika 4: Vpliv spremenjenih vhodnih spremenljivk na mehanske lastnosti: a) krčenje, b) specifično delo pri pretrgu, c) trdnost, d) začetni modul. Ker je spreminjanje $T S D R$ večje od drugih parametrov, je to prikazano na desni vertikalni osi na sliki 4a.

effect on the shrinkage. The internal stress achieved with the third-stage draw ratio increases the fiber shrinkage. This is related to the absence of heat in the third stage of drawing. A further crystallization after a critical TSDR, along with an increase in the orientation of the amorphous region, led to a negligible change in the shrinkage value. According to Figure $\mathbf{4 b}$, the effects of the FSDR, $S S D R$ and TSDR on the specific work of rupture are the same and the effect of the $S G T$ is also very similar to them. By increasing these parameters, a decrease in the specific work of rupture can be achieved. But the BHT has an opposite effect on this parameter and an increase in the $B H T$ gives rise to an increase in the specific work of rupture. After a critical $B H T$, a reorientation begins which is accompanied by a decrease in the orientation and confirmed by a significant increase in the specific work of rupture. Moreover, the FGT has no appreciable effect on the specific work of rupture.

Based on Figure $\mathbf{4 c}$ and considering the tenacity variation, the variables can be divided into effective/ non-effective categories; the $F G T, B H T$ and $S G T$ are categorized as the non-effective group, while the FSDR, $S S D R$, and TSDR are considered as the effective group. By increasing the values of the effective group, the tenacity increases, and with even higher values the tenacity almost reaches the plateau. As shown in Figure 4d, the initial modulus increases due to the increased FSDR, SSDR, TSDR and SGT, while the FGT and BHT have no visible effect on the initial modulus. It seems that the temperature of the block heater mainly affects the crys- talline structure of the fibers that restricts the chain orientation in the third stage of drawing. This explains why the initial modulus did not change significantly as the $B H T$ increased.

\subsection{Important index analysis of the ANN model}

To study the contributions of different input variables to the ANN output model, various methods were introduced, like the weights method ${ }^{29,30}$. A modified weights method was introduced by Gevrey et al. ${ }^{31}$ and their results are very close to the weights method. In this study, the modified weights method was implemented to determine the percentage contribution of each input variable to the physical properties. Referring to the modified weight method and Figure 1, the relative importance $(R I)$ is calculated through Equations (2) and (3):

$$
\begin{gathered}
Q_{j}=\frac{\left|w_{i j}\right|}{\sum_{i=1}^{n}\left|w_{i j}\right|}, j=1,2, \ldots, m \\
R I_{i}=\frac{\sum_{j=1}^{m} Q_{i j}}{\sum_{j=1}^{m} \sum_{i=1}^{n} Q_{i j}} \times 100
\end{gathered}
$$

It must be noted that only the first hidden layer is considered in the modified weights method. The RI values for all the input variables were obtained and shown in Figure 5. 


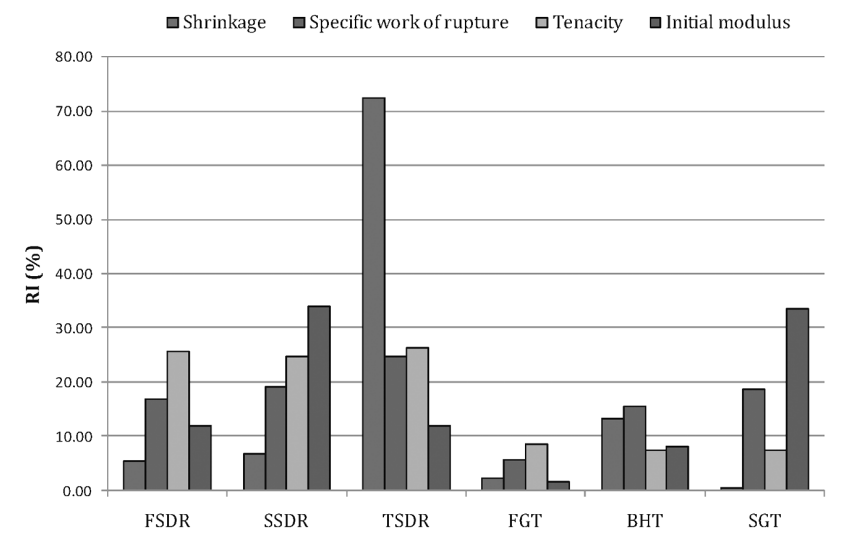

Figure 5: $R I$ for all the input variables versus the physical properties Slika 5: $R I$ vseh vhodnih spremenljivk proti fizikalnim lastnostim

Figure 5 indicates that the main effect of the TSDR is more pronounced on the shrinkage than the other factors and that among the temperature variables, the BHT plays the main role. In the case of the tenacity, although all the draw ratios and temperatures influence this mechanical property, the tenacity of drawn fibers is primarily governed by the draw ratios. The initial modulus and the specific work of rupture correlate with all the variables except for the FGT. Among them, the second-stage drawing variables have significant effects on the initial modulus.

\section{CONCLUSION}

The results of this investigation suggest that an ANN can be used quite effectively for a prediction of the physical properties of drawn fibers. The ANN approach was better at fitting the measured response in comparison to the regression model. According to the obtained results, it can be seen that, though only a limited number of samples were available for the training and testing, the overall prediction capabilities of the models were good and would be very useful for optimizing the hot multistage drawing process with regard to the time, quality and price.

Among the variables, the first-godet temperature had no significant effect on the physical properties. The shrinkage was governed by the third-stage draw ratio and the draw ratios were the variables affecting the tenacity. The second-stage drawing variables played the main roles in determining the initial modulus, while the specific work of rupture was governed by the draw ratios and the second-godet temperature.

\section{REFERENCES}

${ }^{1}$ D. R. Salem (Ed.), Structure formation in polymeric fibers, Hanser Publishers, Munich 2000, 118-184

${ }^{2}$ R. Yang, R. R. Mather, A. F. Fotheringham, Processing, structure, and mechanical properties of as-spun polypropylene filaments - A systematic approach using factorial design and statistical analysis, Journal of Applied Polymer Science, 96 (2005) 1, 144-154, doi:10. 1002/app.21416
${ }^{3}$ R. Yang, R. R. Mather, A. F. Fotheringham, The influence of processing parameters on the structural and mechanical properties of drawn polypropylene fibres: A factorial design approach, Journal of Applied Polymer Science, 124 (2012) 5, 3606-3616, doi:10.1002/ app. 34738

${ }^{4}$ R. D. Yang, R. R. Mather, A. F. Fotheringham, The application of factorial experimental design to the processing of polypropylene fibres, Journal of Materials Science, 36 (2001) 13, 3097-3101, doi:10.1023/A:1017909630132

${ }^{5}$ B. Younes, A. Fotheringham, R. Mather, Statistical analysis of the effect of multi-stage hot drawing on the thermal shrinkage and crystallographic order of biodegradable aliphatic-aromatic co-polyester fibres, Fibers and Polymers, 12 (2011) 6, 778-788, doi:10.1007/ s12221-011-0778-9

${ }^{6}$ F. Arain, A. Tanwari, T. Hussain, Z. Malik, Multiple response optimization of rotor yarn for strength, unevenness, hairiness and imperfections, Fibers and Polymers, 13 (2012) 1, 118-122, doi:10.1007/ s12221-012-0118-8

${ }^{7}$ K. Yildirim, Y. Ulcay, O. Kopmaz, Forming Regression-based Mathematical Models to Predict PET POY Yarn Properties in the Case of Changing Production Parameters, Textile Research Journal, 80 (2010) 5, 411-421, doi:10.1177/0040517509346437

${ }^{8}$ B. Younes, A. Fotheringham, H. M. El-Dessouky, G. Hadda, A Statistical Analysis of the Influence of Multi-Stage Hot-Drawing on the Overall Orientation of Biodegradable Aliphatic-Aromatic Co-Polyester Fibers, Journal of Engineered Fibers and Fabrics, 8 (2013) 1, 6-16

${ }^{9}$ M. D. Teli, R. Chakrabarti, Use of Statistical Methods to Understand the Effect of Yarn and Fabric Parameters on Desizing Efficiency, Fibres \& Textiles in Eastern Europe, 16 (2008) 2, 95-100

${ }^{10}$ L. J. Strumillo, D. Cyniak, J. Czekalski, T. Jackowski, Neural Model of the Spinning Process Dedicated to Predicting Properties of Cotton-Polyester Blended Yarns on the Basis of the Characteristics of Feeding Streams, Fibres \& Textiles in Eastern Europe, 16 (2008) $1,28-36$

${ }^{11}$ A. Moghassem, A. Fallahpour, M. Shanbeh, An intelligent model to predict breaking strength of rotor spun yarns using gene expression programming, Journal of Engineered Fibers and Fabrics, 7 (2012) 2, $1-10$

${ }^{12}$ A. A. Gharehaghaji, M. Shanbeh, M. Palhang, Analysis of two modeling methodologies for predicting the tensile properties of cotton-covered nylon core yarns, Textile Research Journal, 77 (2007) 8, 565-571, doi:10.1177/0040517507078061

${ }^{13}$ C. F. J. Kuo, K. I. Hsiao, Y. S. Wu, Using neural network theory to predict the properties of melt spun fibers, Textile Research Journal, 74 (2004) 9, 840-843, doi:10.1177/004051750407400914

${ }^{14}$ G. Allan, R. Yang, A. Fotheringham, R. Mather, Neural modelling of polypropylene fibre processing: Predicting the structure and properties and identifying the control parameters for specified fibres, Journal of Materials Science, 36 (2001) 13, 3113-3118, doi:10.1023/ a:1017913731041

${ }^{15}$ G. Yao, J. Guo, Y. Zhou, Predicting the warp breakage rate in weaving by neural network techniques, Textile Research Journal, 75 (2005) 3, 274-278, doi:10.1177/004051750507500314

${ }^{16} \mathrm{O}$. Balc1, R. Tuğrul Oğulata, Prediction of the changes on the CIELab values of fabric after chemical finishing using artificial neural network and linear regression models, Fibers Polym, 10 (2009) 3, 384-393, doi:10.1007/s12221-009-0384-2

${ }^{17}$ A. Rawal, A. Majumdar, S. Anand, T. Shah, Predicting the properties of needlepunched nonwovens using artificial neural network, Journal of Applied Polymer Science, 112 (2009) 6, 3575-3581, doi:10.1002/ app. 29687

${ }^{18}$ M. M. Yazdi, D. Semnani, M. Sheikhzadeh, Moisture and heat transfer in hybrid weft knitted fabric with artificial intelligence, Journal of Applied Polymer Science, 114 (2009) 3, 1731-1737, doi:10.1002/ app.30685 


\section{R. S. RAHBAR, M. VADOOD: PREDICTING THE PHYSICAL PROPERTIES OF DRAWN NYLON-6 FIBERS ...}

${ }^{19}$ M. Vadood, D. Semnani, M. Morshed, Optimization of acrylic dry spinning production line by using artificial neural network and genetic algorithm, Journal of Applied Polymer Science, 120 (2011) 2, 735-744, doi:10.1002/app.33252

${ }^{20}$ O. N. Hung, L. J. Song, C. K. Chan, C. W. Kan, C. W. M. Yuen, Using artificial neural network to predict colour properties of laser-treated $100 \%$ cotton fabric, Fibers Polym, 12 (2011) 8, 1069-1076, doi:10.1007/s12221-011-1069-1

${ }^{21}$ D. Semnani, M. Vadood, Improvement of intelligent methods for evaluating the apparent quality of knitted fabrics, Engineering Applications of Artificial Intelligence, 23 (2010) 2, 217-221, doi:10.1016/j.engappai.2009.08.003

${ }^{22}$ P. Unal, M. Üreyen, D. Mecit, Predicting properties of single jersey fabrics using regression and artificial neural network models, Fibers Polym, 13 (2012) 1, 87-95, doi:10.1007/s12221-012-0087-y

${ }^{23}$ K. Nasouri, H. Bahrambeygi, A. Rabbi, A. M. Shoushtari, A. Kaflou, Modeling and optimization of electrospun PAN nanofiber diameter using response surface methodology and artificial neural networks, Journal of Applied Polymer Science, 126 (2012) 1, 127-135, doi:10.1002/app.36726

${ }^{24}$ T. Chen, C. Zhang, L. Li, X. Chen, Simulating the drawing of spunbonding nonwoven process using an artificial neural network technique, Journal of The Textile Institute, 99 (2008) 5, 479-488, doi:10.1080/00405000701608631
${ }^{25}$ P. Soltani, M. Vadood, M. Johari, Modeling spun yarns migratory properties using artificial neural network, Fibers Polym, 13 (2012) 9, 1190-1195, doi:10.1007/s12221-012-1190-9

${ }^{26}$ R. Semnani Rahbar, M. R. M. Mojtahedi, Influence of hot multistage drawing on structure and mechanical properties of nylon 6 multifilament yarn, Journal of Engineered Fibers and Fabrics, 6 (2011) 2 , $7-15$

${ }^{27}$ L. Fausett, Fundamentals of neural networks, Prentice Hall, New Jersey 1994

${ }^{28}$ I. Belič, Neural Networks and Static Modelling, In: M. ElHefnawi, M. Mysara (Eds.), Recurrent Neural Networks and Soft Computing, InTech [online]. 2012, 1, 1-21. Available from:

http://www.intechopen.com/books/recurrent-neural-networks-and-so ft-computing/neural-networks-and-static-modelling

${ }^{29}$ A. T. C. Goh, Back-propagation neural networks for modeling complex systems, Artificial Intelligence in Engineering, 9 (1995) 3, 143-151, doi:10.1016/0954-1810(94)00011-S

${ }^{30}$ G. D. Garson, Interpreting neural network connection weights, Artificial Intelligence Expert, 6 (1991) 4, 46-51

${ }^{31}$ M. Gevrey, I. Dimopoulos, S. Lek, Review and comparison of methods to study the contribution of variables in artificial neural network models, Ecological Modelling, 160 (2003) 3, 249-264, doi:10.1016/S0304-3800(02)00257-0 